\title{
Stavovi stanovništva o cijepljenju djece u Brčko distriktu $\mathrm{BiH}$
}

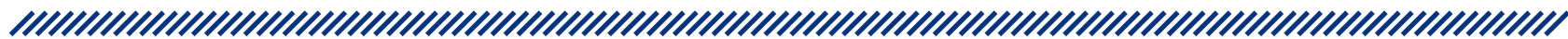

1 Adis Puška

2 Sead Šadić

1 Institut za znanstvena istraživanja i tehniku, Brčko distrikt BiH

2 Vlada Brčko distrikta BiH, Brčko distrikt BiH stav prema negacijskim pitanjima pozitivan stav prema afirmacijskim pitanjima i obratno. Analiza varijance dokazala je da su stavovi ispitanika nepromijenjeni i stalni. Ovo istraživanje dalo je dobre temelje za razumijevanje stavova stanovništva prema cijepljenju djece koji bi se sljedećim istraživanjima još produbili te bi poslužili za izradu strategija za cijepljenje djece u javnom zdravstvu.

\section{Sažetak}

Cijepljenje je najveće postignuće u medicini za liječenje zaraznih bolesti. Cijepljenjem su neke zarazne bolesti iskorijenjene, dok su druge gotovo iskorijenjene. Međutim, i uz to neki roditelji ne cijepe svoju djecu. Na to utječu njihovi stavovi prema cijepljenju. Ovaj se rad bavi istraživanjem stavova stanovništva prema cijepljenju. Istraživanje je provedeno na teritoriju Brčko distrikta BiH te je primijenjen mrežni anketni upitnik. S pomoću anketnog upitnika najprije su dobiveni podaci o karakteristikama ispitanika, a u drugom dijelu upitnika ispitani su njihovi stavovi prema cijepljenju djece. Istraživačka faktorska analiza (EFA) grupirala je obje skupine tvrdnji u dva faktora.

Ispitivanje stavova stanovništva prema cijepljenju provedeno je s pomoću dvije skupine od po 13 pitanja, i to afirmacijskih i negacijskih pitanja o cijepljenju. $\mathrm{Na}$ temelju dobivenih odgovora izvršeno je grupiranje ispitanika prema njihovim stavovima, i to: ako je većina odgovora ispitanika bila pozitivna, onda su oni grupirani u skupinu ispitanika koji imaju pozitivan stav i obratno. Istraženo je imaju li ispitanici koji su imali negativan

Ključne riječi: cijepljenje djece, stavovi stanovništva, cijepljenje, faktorska analiza, analiza varijance

Datum primitka: 25.09.2018.

Datum prihvaćanja: 15.10.2018.

DOI: $10.24141 / 1 / 4 / 2 / 3$

Adresa za dopisivanje:

Adis Puška

Institut za znanstvena istraživanja i tehnologiju, Adila ef. Čokića br. 32, 76120 Brčko distrikt BiH

tel.: +38761305535

e-pošta: adispuska@yahoo.com 


\section{Uvod}

Cijepljenje je jedno od najvećih postignuća u medicini i javnom zdravstvu. ${ }^{1}$ Ima važnu ulogu u sprječavanju bolesti lokalne zajednice i svijeta. ${ }^{2}$ Najbolji je način sprječavanja zaraze, kao i razvoja bolesti i njezinih komplikacija. ${ }^{3}$ Smanjilo je smrtnost i morbiditet djece uzrokovane dječjim zaraznim bolestima. ${ }^{4}$ Često se navodi da je cijepljenje najviše pridonijelo globalnom zdravlju. ${ }^{5}$ Poboljšanju globalnog zdravlja pridonijelo je povećanje osobne higijene, upotreba čiste vode i slično, ali tomu je uvelike pridonijelo i cijepljenje. U razvijenijim državama cijepljeno je više od $98 \%$ populacije, ${ }^{1}$ dok je u nerazvijenijim državama ovaj postotak manji. Visoka stopa cijepljene populacije u djetinjstvu ukazuje na to da je cijepljenje široko prihvaćena mjera javnog zdravstva. ${ }^{6}$ Cijepljenje je napravilo ogroman doprinos poboljšanju ljudskog i životinjskog zdravlja, posebice u državama u razvoju. ${ }^{5}$ Održavanje visokih stopa cijepljenja važno je za smanjenje broja oboljenja koja se mogu spriječiti kako kod pojedinaca tako i kod zajednice, jer se kroz cijepljenje povećava imunitet organizama. ${ }^{7}$

U nekim je državama cijepljenje djece obvezno, kao što je u Hrvatskoj, Sloveniji, Češkoj, Poljskoj, Portugalu, Bosni i Hercegovini itd., dok u drugim državama nije obvezno cijepljenje djece te je prepušteno roditeljima da odluče hoće li ili neće cijepiti djecu. To je slučaj u državama kao što su Njemačka, Italija, Španjolska, Austrija itd. Na primjer, iako u Švedskoj cijepljenje nije obvezno, ondje je protiv HPV-a cijepljeno do $76 \%$ mladeži. ${ }^{8} \mathrm{U}$ Sjedinjenim Američkim Državama obvezno je cijepljenje djece koja idu u javne škole, dok nije obvezno za djecu koja pohađaju privatne škole. ${ }^{9}$ Zanimljiv je podatak da je cijepljenje protiv velikih boginja bilo obvezno od 19. stoljeća u Habsburškoj Monarhiji. ${ }^{10}$ Dužnost država u kojima je uvedeno obvezno cijepljenje jest da osiguraju sigurna i učinkovita cjepiva i organiziraju sustav zdravstvene zaštite tako da se cijepljenje omogućuje svima, ${ }^{11}$ kao što je to regulirano u Republici Hrvatskoj.

S razvojem socijalnih mreža počele su se voditi polemike o tome koliko je cijepljenje sigurno. U SAD-u je prisutno jačanje pokreta protiv cijepljenja, gdje je strah od potencijalno smrtonosnih bolesti zamijenjen strahom od neželjenih učinaka cijepljenja. Ovaj strah potiču pokreti protiv cijepljenja s pomoću medija (interneta, prvenstveno socijalnih mreža), poznatih ličnosti i političara. ${ }^{12}$ Istraživanja pokazuju da se u Sjevernoj Americi,
Europi i drugim dijelovima svijeta povjerenje javnosti u cjepiva smanjuje, a pokreti protiv cijepljenja postaju sve jači. ${ }^{13}$ Burghouts i sur. na primjeru društvene zajednice Warao Amerindians utvrdili su da su strah od neželjenih učinaka i ideja da su djeca previše mlada te previše ranjiva da bi se cijepila negativno utjecali na prihvaćanje cjepiva. ${ }^{14}$ Osim toga, mnogi roditelji, iako cijepe djecu, imaju strah od toga kako će se cijepljenje odraziti na zdravlje njihove djece..$^{15}$ Također se navodi i ekonomska isplativost pojedinih vrsta cijepljenja. ${ }^{16} \mathrm{U}$ Hrvatskoj je uočen problem da se pripadnici romske nacionalne manjine ne odazivaju obveznom cijepljenju ${ }^{17}$ pa je u okviru projekta Desetljeće za Rome povedena akcija informiranja ove nacionalne manjine o važnosti i obvezi cijepljenja djece.

Cijepljenje sve više dobiva pažnju javnosti u razvijenim državama i državama u razvoju u svijetu. ${ }^{6}$ Sve više roditelja odbija cijepiti djecu zbog straha od nuspojava i nije upoznato $s$ rizikom takvog ponašanja, ${ }^{18}$ iako, prema podacima iz različitih studija, stvarna učestalost alergijskih reakcija na cijepljenja varira od 0,65 do 1,53 slučaja na milijun doza cjepiva. ${ }^{19}$ Javna se zdravstva bore protiv ovih udruga naglašavajući važnost cijepljenja kod djece. Olpinski kaže da ne postoji lako rješenje za problem necijepljenja djece, ${ }^{12}$ najvažnije je nastaviti s javnim obrazovanjem i uvjeravanjem te slušanjem roditeljskih problema i diskutiranjem o rizicima od necijepljenja. Yaqub i sur. kažu da je za rješavanje problema necijepljenja djece potrebno primijeniti koordiniranu strategiju kod svih interesnih skupina ${ }^{20}$ jer će se tako spoznati važnost cijepljenja kod djece. Da bi se spriječile infekcije i imunološke reakcije na cjepivo i tako utjecalo na svijest stanovništva o potrebi cijepljenja, potrebno je ispitivanje triju važnih čimbenika povezanih s cijepljenjem djece, a to su: sigurnost cijepljenja, učinkovitost cijepljenja i potencijalna korist određenih cijepljenja. ${ }^{21}$ Ako se uspješno odgovori na ova pitanja, poboljšat će se stanje glede cijepljenja djece.

Međutim, istraživanja o prihvaćanju cjepiva pokazala su da je pojedinačno donošenje odluka u vezi s cijepljenjem daleko složenije i može uključiti emocionalne, kulturne, društvene, duhovne ili političke faktore, kao i kognitivne faktore. ${ }^{22,23}$ Glavni razlozi za necijepljenje u povezani su s uslugama cijepljenja te roditeljskim znanjem i stavovima. ${ }^{24}$ Burghouts i sur. kažu da je niska stopa cijepljenja djece uobičajena kod autohtonih populacija, u kojima roditelji često odluče ne cijepiti svoju djecu. ${ }^{14}$ Cvjetković i sur. utvrdili su da u Srbiji liječnici, a posebice pedijatri preporučuju cijepljenje i oni su u ključnoj poziciji da komuniciraju i unaprjeđuju pred- 
nosti imunizacije djece. ${ }^{25}$ Međutim, moraju imati bolje znanje i pozitivnije stavove kako bi bili uspješniji u promociji imunizacije. Dobar primjer predstavlja Hrvatska, gdje je nacionalni program obveznog cijepljenja jedna je od najopsežnijih i najuspješnijih preventivnih zdravstvenih akcija u državi. ${ }^{26}$ Zbog toga ostalim državama treba biti primjer Republika Hrvatska i kako je ona riješila pitanje cijepljenja.

U BiH je cijepljenje obvezno za djecu od rođenja i mlade do 18. godine protiv deset infektivnih bolesti. Međutim, i uz zakonsku obvezu djeca se ne cijepe jer stavovi njihovih roditelja utječu na to. Veoma je važno istražiti stavove roditelja i stanovništva o cijepljenju djece kako bi se stekao bolji uvid. Cilj je ovoga rada upravo ispitivanje stavova stanovništva o cijepljenju djece na području Brčko distrikta BiH. Rezultati dobiveni ovom studijom pomoći će javnom zdravstvu da spozna koji su pozitivni, a koji negativni stavovi o cijepljenju djece kod stanovništva. Na temelju rezultata bit će moguće izraditi strategije o jačanju važnosti cijepljenja kako kod roditelja tako i kod ostalog stanovništva, jer samo pravim informacijama i pravim akcijama moguće je povećati broj cijepljene djece te tako izbjeći eventualne epidemije.

Osim toga, postavljaju se i sljedeći ciljevi ovoga rada:

1. ispitati stavove građanstva Brčko distrikta BiH o cijepljenju djece

2. ustanoviti skupine građanstva na temelju stavova o cijepljenju djece

3. usporediti skupine građanstva i ustanoviti jesu li njihovi stavovi stalni i nepromjenjivi.

$\mathrm{Na}$ temelju ovih ciljeva postavlja se i hipoteza istraživanja koja glasi:

H: Stavovi građanstva Brčko distrikta stalni su i nepromjenjivi glede vakcinacije djece

Nakon uvoda najprije će se objasniti primijenjene metode u ovom istraživanju i metodologija istraživanja, izvršit će se statistička obrada podataka te će se kroz diskusiju ti rezultati obrazložiti i izvući jasni zaključci o tome kako poboljšati cijepljenje kod djece kako na području Brčko distrikta BiH tako i na području čitave BiH. Dobiveni rezultati ovoga istraživanja komparirat će se $s$ rezultatima provedenih istraživanja u drugim državama svijeta te će se tako dobiti globalna slika o stavovima stanovništva o cijepljenju djece.

\section{Materijal i metode}

\subsection{Procedure i sudionici}

Istraživanje za potrebe ovoga rada provedeno je na području Brčko distrikta BiH u veljači 2018. godine. Ciljna skupina za popunu ovoga upitnika bili su svi građani Brčko distrikta BiH stariji od 15 godina. Cilj ovoga istraživanja bio je da se ispitaju stavovi građana o dječjem cijepljenju. Kod prikupljanja podataka korišten je namjerni prigodni uzorak. Istraživanje je provedeno putem mrežne ankete postavljene na znanstvenom portalu 1 ka.si. Anketa je putem URL pozivnice distribuirana građanima. Pri tome su korištene društvene mreže, prvenstveno Facebook.

Za popunjavanje ove ankete građanima je trebalo $\mathrm{u}$ prosjeku pet minuta. Svi odgovori bili su anonimni i tome se posvetilo najviše pažnje, kako da se ne bi utjecalo na ispitanika da ne izrazi svoje stavove. U uvodnom dijelu anketnog upitnika objašnjena je svrha istraživanja, a sudionici su pozvani povjerljivo završiti istraživanje. Sudjelovanje $u$ istraživanju bilo je dobrovoljnog karaktera te sudionici nisu dobili nikakvu vrstu nagrade. Namjerno je izbjegavano slanje upitnika elektroničkom poštom da bi se očuvala anonimnost sudionika.

\subsection{Instrument istraživanja i mjerenje}

Anketni upitnik izrađen je nakon detaljne razrade literature i upotrebom ranijih kvalitativnih studija koje su proveli sljedeći autori: Pelly i sur., ${ }^{27}$ Mollema i sur., ${ }^{28}$ Lameris i sur., ${ }^{29}$ Yousif i sur., ${ }^{30}$ Elbur i sur., ${ }^{31}$ Cvjetković i sur. ${ }^{25}$

Nakon što su prikupljena pitanja i napravljen probni anketni upitnik, poslan je trojici stručnjaka da ga pregledaju i da daju svoje mišljenje o njemu. Nakon toga anketni je upitnik korigiran u skladu s mišljenjima stručnjaka koja su se odnosila na razumijevanje sadržaja upitnika i prilagodbu običnim građanima. Anketni upitnik podijeljen je u tri dijela.

U prvom dijelu od sudionika je zatraženo da popune svoje demografske karakteristike, koje su se odnosile na: spol, visinu primanja kućanstva, obrazovanje, radni status, dob, bračni status, broj članova u kućanstvu te broj djece u obitelji. Na temelju tih pitanja dobiveni su podaci o samim sudionicima.

Drugi dio upitnika sadržavao je 13 pitanja koja su afirmacijskog tipa o cijepljenju djece u obliku Likertove lje- 
stvice s pet stupnjeva neslaganja odnosno slaganja, na koja su sudionici trebali dati svoje mišljenje. Treći dio upitnika sadržavao je 13 pitanja koja su negacijskog tipa o cijepljenju u vidu Likertove ljestvice s pet stupnjeva neslaganja odnosno slaganja s pomoću kojih su ispitanici davali svoje mišljenje.

\subsection{Analiza podataka}

Prilikom analize dobivenih podataka primijenjene su različite statističke metode. Deskriptivna statistika primijenjena je za davanje detaljnih informacija o ispitanicima i za zbirno predstavljanje varijabli istraživanja. Istraživačka faktorska analiza (EFA) primijenjena je da bi se tvrdnje grupirale u odgovarajuće skupine. Da bi se ispitali rezultati EFA-e primijenjeni su pokazatelji Kaiser-Meyer-Olkinova (KMO) adekvatnost uzorka te Bartlettov test sferičnosti. Vrijednost pokazatelja KMO mora biti veća od 0,6 da bi korelacijska matrica bila prihvatljiva za analizu, dok vrijednost razine značajnosti Bartlettova testa sferičnosti mora biti manja od 0,05 $(p<0,05) .{ }^{32}$ Prilikom provedbe EFA-e primijenjena je $v a$ rimax rotacija faktora te Kaiserova normalizacija. Pouzdanost mjerne ljestvice prikupljenih podataka ispitala se s pomoću Cronbachova alfa koeficijenta. Vrijednost ovoga pokazatelja mora biti veća od 0,7 kako bi se podaci smatrali prikladnima za analizu.

Kada se ispitaju podaci i grupiraju u odgovarajuće skupine, potrebno je ispitati analizom varijance (ANOVA) razlikuju li se sredine određenih skupina međusobno. Skupine ispitanika formiraju se tako što će se vrednovati odgovori na afirmacijska pitanja o cijepljenju i sumirati odgovori. Ako se zbroj odgovora kreće od 13 do 34 , smatra se da ti ispitanici imaju negativne stavove prema cijepljenju; ako je zbroj od 35 do 44, smatra se da ti ispitanici imaju neutralne stavove prema cijepljenju; a ako je zbroj od 45 do 65 , smatra se da ti ispitanici imaju pozitivne stavove prema cijepljenju. Formirane skupine primijenit će se na negacijski dio pitanja $i$ ispitat će se s pomoću analize ANOVA postoji li značajna statistička razlika između ovih skupina kod skupine negacijskih pitanja za cijepljenje. $\mathrm{Na}$ isti način formirat će se tri skupine ispitanika iz negacijskih pitanja te će se te skupine primijeniti za afirmacijski dio pitanja, samo što će za najmanji interval zbroja biti grupirani ispitanici koji imaju pozitivne stavove prema cijepljenju, dok će se za najveći interval zbroja grupirati ispitanici koji imaju negativne stavove prema cijepljenju. Tako će se ispitati jesu li stavovi građana konstantni i nepromjenjivi. Sve ove analize provest će se putem statističkog paketa SPSS.

\section{Rezultati}

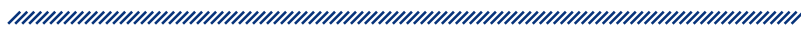

Podaci za potrebe ovoga rada prikupljeni su od građana iz Brčko distrikta BiH s pomoću mrežne ankete. Anketi su pristupila 623 ispitanika, dok su anketu popunila 144 ispitanika. Međutim, 27 anketa nisu bile popunjene više od $70 \%$ pa su isključene iz daljnje analize. Anketiranje je provedeno u veljači 2018. godine. Karakteristike ispitanika prikazane su u tablici 1.

Budući da su primijenjene dvije skupine tvrdnji raspoređene $u$ afirmacijske i negacijske tvrdnje, najprije će se kod svih analiza obraditi afirmacijske tvrdnje pa onda negacijske. Prije nego što se provede analiza EFA, potrebno je ispitati pouzdanost mjerne ljestvice s pomoću Cronbachova alfa koeficijenta (tablica 2). Rezultati ovoga pokazatelja za sve su tvrdnje više od 0,7 pa se može zaključiti da je mjerna ljestvica koja je primijenjena kod ispitivanja stavova kod stanovništva pouzdana. S pomoću vrijednosti korigiranog koeficijenta (ukupne korelacije kojom se mjeri stupanj povezanosti pojedine tvrdnje s ukupnim tvrdnjama) ispitano je mjeri li pojedina tvrdnja nešto drugo. Budući da je vrijednost ovoga pokazatelja veća od 0,3 , može se zaključiti da sve tvrdnje podjednako mjere stavove stanovništva o cijepljenju djece.

Provedena analiza EFA (tablica 2) pokazuje da se sve tvrdnje grupiraju u dva faktora. Rezultati KMO-a $(0,914)$ i Bartlettova testa $(p<0,000)$ pokazuju da su rezultati EFA-e pouzdani. Prvi faktor čini devet tvrdnji, a njime je objašnjeno 55,25\% varijance, drugi faktor čine četiri tvrdnje i on objašnjava $8,71 \%$ varijance. Promatrajući deskriptivnu statistiku može se zaključiti da su ispitanici najsuglasniji s tvrdnjom „Liječnik ima važnu ulogu u obrazovanju roditelja o važnosti cijepljenja u djetinjstvu" (prosjek $=4,15$ ), dok su najmanje suglasni s tvrdnjom „Davanje više cjepiva odjednom nema negativnih utjecaja na imunitet djece" (prosjek $=2,58$ ).

Kada se promatraju faktori može se uočiti da u drugi faktor ulaze tvrdnje koje imaju najmanju prosječnu vrijednost odgovora. To su tvrdnje o sigurnosti cijepljenja, cijepljenju za sezonske gripe i davanju više cjepiva odjednom. Najveću disperziju kod dobivenih odgovora od ispitanika imamo kod tvrdnje „Važno je cijepiti stanovništvo kako bi se izbjegla pojava novih epidemija", kod koje je najveća vrijednost standardne devijacije ( $S D=1,215)$, dok je najmanja disperzija u dobivenim odgovorima kod tvrdnje „Liječnik ima važnu ulogu u obrazovanju roditelja o važnosti cijepljenja u djetinjstvu" 


\begin{tabular}{|c|c|c|c|}
\hline \multicolumn{2}{|c|}{ Demografske karakteristike } & Frekvencija & Postotak \\
\hline \multirow{2}{*}{ Spol ispitanika: } & muški & 37 & 31,6 \\
\hline & ženski & 80 & 68,4 \\
\hline \multirow{5}{*}{ Visina primanja kućanstva u KM: } & do 500 & 11 & 9,4 \\
\hline & $501-1.000$ & 15 & 12,8 \\
\hline & $1.001-1.500$ & 36 & 30,8 \\
\hline & $1.501-2.000$ & 27 & 23,1 \\
\hline & više od 2.001 & 28 & 23,9 \\
\hline \multirow{3}{*}{ Obrazovanje ispitanika: } & srednja & 20 & 17,1 \\
\hline & viša & 70 & 59,8 \\
\hline & visoka & 27 & 23,1 \\
\hline \multirow{3}{*}{ Radni status: } & učenik, student & 4 & 3,4 \\
\hline & zaposlen & 95 & 81,2 \\
\hline & nezaposlen & 18 & 15,4 \\
\hline \multirow{5}{*}{ Dob ispitanika: } & $15-24$ & 8 & 6,8 \\
\hline & $25-35$ & 69 & 59,0 \\
\hline & $36-45$ & 29 & 24,8 \\
\hline & $46-55$ & 8 & 6,8 \\
\hline & 56 i više & 3 & 2,6 \\
\hline \multirow{4}{*}{ Bračni status } & u braku & 84 & 71,8 \\
\hline & neoženjen/neudana & 24 & 20,5 \\
\hline & razveden/razvedena & 7 & 6,0 \\
\hline & udovac/udovica & 2 & 1,7 \\
\hline \multirow{5}{*}{ Broj članova u kućanstvu: } & $1-2$ & 27 & 23,1 \\
\hline & 3 & 42 & 35,9 \\
\hline & 4 & 37 & 32,5 \\
\hline & $5-6$ & 7 & 6,0 \\
\hline & 7 i više & 3 & 2,6 \\
\hline \multirow{5}{*}{ Broj djece u obitelji: } & bez djece & 34 & 29,1 \\
\hline & 1 & 44 & 37,6 \\
\hline & 2 & 33 & 28,2 \\
\hline & 3 & 3 & 2,6 \\
\hline & 4 i više & 3 & 2,6 \\
\hline
\end{tabular}

$(S D=0,784)$. Vrijednost standardne devijacije označava kod koje su tvrdnje najujednačeniji odgovori kod ispitanika (kod tih tvrdnja manja je vrijednost standardne devijacije), odnosno najneujednačeniji (kod tih tvrdnja veća je vrijednost standardne devijacije).

Drugom analizom EFA (tablica 3) tvrdnje su također grupirane u dva faktora. Prvim faktorom objašnjeno je 60,81\% varijance, dok je drugim faktorom objašnjeno $8,19 \%$ varijance. Vrijednosti KMO-a $(0,928)$ i Bartlettova testa $(p<0,000)$ pokazuju da su ovi rezultati EFA-e pouzdani. Vrijednosti Cronbachova alfa koeficijenta viši su od 0,7 , čime se potvrđuje pouzdanost mjerne ljestvice. Također su vrijednosti korigiranog koeficijenta korelacije veći od 0,3, čime se potvrđuje ispravnost primijenjenih tvrdnji.

Ispitanici su najsložniji kod tvrdnje „Dijete može oboljeti od zarazne bolesti iako je cijepljeno protiv nje", kod 


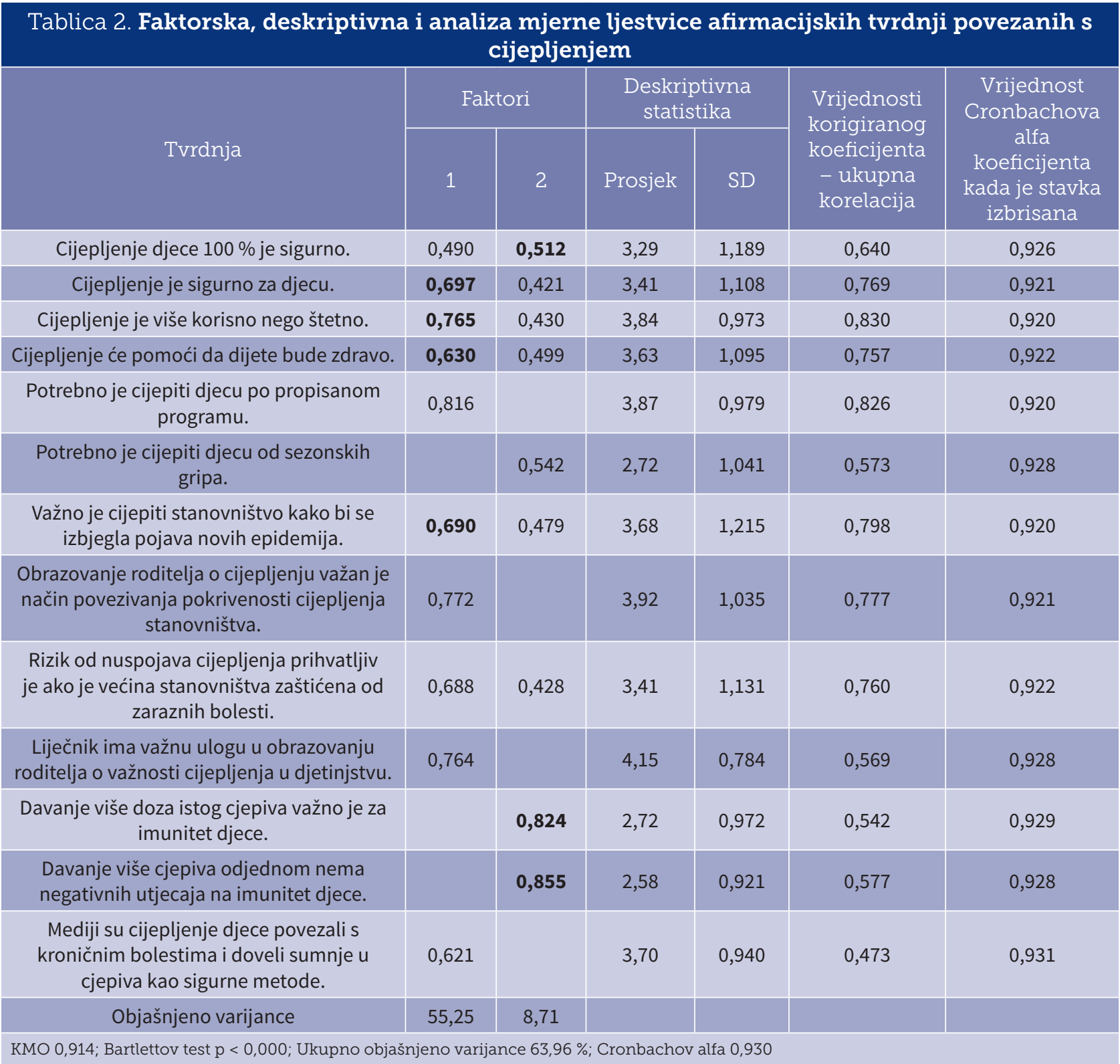

koje je najveća vrijednost prosjeka $(3,50)$, dok se najmanje ne slažu s tvrdnjom „Više nije potrebno cijepiti djecu jer su te bolesti danas rijetke", kod koje je vrijednost prosjeka $(2,11)$ najmanja. Najveća je disperzija u odgovorima (SD = 1,301) kod tvrdnje „Roditelji bi trebali donositi odluku o cijepljenju djece", dok je najmanja disperzija $(S D=0,896)$ kod tvrdnje „Više nije potrebno cijepiti djecu jer su te bolesti danas rijetke".

Prilikom provedbe analize ANOVA uspoređeno je imaju li ispitanici koji imaju negativne stavove na negacijske tvrdnje pozitivne stavove na afirmacijske stavove i obratno. Kao što se može vidjeti, 62 ispitanika imaju pozitivan stav prema cijepljenju djece, 36 ispitanika ima neutralan stav, dok 19 ispitanika ima negativan stav prema cijepljenju djece. Međutim, rezultati dobiveni analizom ANOVA (tablica 4) pokazuju da kod svih 13 tvrdnji postoji značajna statistička ovisnost između odgovora ispitanika kod ovih skupina. Na temelju toga može se zaključiti da su ispitanici zadržali svoje stavove iako su primjenjivana afirmacijska pitanja za cijepljenje.

Najveća je statistička razlika u ponuđenim odgovorima kod tvrdnje "Cijepljenje će pomoći da dijete bude zdravo" (f-test $=66,471$ ), dok je najmanja razlika kod tvrdnje „Mediji su cijepljenje djece povezali s kroničnim bole- 


\section{Tablica 3. Faktorska, deskriptivna i analiza mjerne ljestvice negacijskih tvrdnji povezanih s} cijepljenjem

\begin{tabular}{|c|c|c|c|c|c|c|}
\hline \multirow[b]{2}{*}{ Tvrdnja } & \multicolumn{2}{|c|}{ Faktori } & \multicolumn{2}{|c|}{$\begin{array}{l}\text { Deskriptivna } \\
\text { statistika }\end{array}$} & \multirow{2}{*}{$\begin{array}{c}\text { Vrijednosti } \\
\text { korigiranog } \\
\text { koeficijenta } \\
\text { - ukupna } \\
\text { korelacija }\end{array}$} & \multirow{2}{*}{$\begin{array}{c}\text { Vrijednost } \\
\text { Cronbachova } \\
\text { alfa } \\
\text { koeficijenta } \\
\text { kada je stavka } \\
\text { izbrisana }\end{array}$} \\
\hline & 1 & 2 & Prosjek & SD & & \\
\hline $\begin{array}{l}\text { Farmaceutske kuće propagiraju cijepljenje } \\
\text { radi profita iako su cjepiva štetna. }\end{array}$ & & 0,729 & 2,84 & 1,027 & 0,638 & 0,942 \\
\hline $\begin{array}{l}\text { Cjepiva sadrže tvari koje su štetne za } \\
\text { zdravlje djece. }\end{array}$ & & 0,881 & 2,76 & 0,995 & 0,622 & 0,942 \\
\hline $\begin{array}{l}\text { Više nije potrebno cijepiti djecu jer su te } \\
\text { bolesti danas rijetke. }\end{array}$ & 0,518 & 0,675 & 2,11 & 0,896 & 0,797 & 0,938 \\
\hline $\begin{array}{c}\text { Neke su zarazne bolesti nestale zbog bolje } \\
\text { higijene pa se djeca ne moraju cijepiti protiv } \\
\text { njih. }\end{array}$ & 0,622 & 0,592 & 2,28 & 1,052 & 0,822 & 0,937 \\
\hline $\begin{array}{l}\text { Bespotrebno je cijepiti djecu protiv zaraznih } \\
\text { bolesti koje više ne postoje. }\end{array}$ & 0,675 & 0,554 & 2,34 & 1,090 & 0,835 & 0,936 \\
\hline $\begin{array}{l}\text { Država nema pravo nametati obvezno } \\
\text { cijepljenje djece. }\end{array}$ & 0,845 & & 2,84 & 1,274 & 0,741 & 0,939 \\
\hline $\begin{array}{l}\text { Roditelji bi trebali donositi odluku o } \\
\text { cijepljenju djece. }\end{array}$ & 0,897 & & 3,20 & 1,301 & 0,705 & 0,941 \\
\hline $\begin{array}{c}\text { Nema dovoljno dokaza da cijepljenje } \\
\text { sprječava zarazne bolesti. }\end{array}$ & 0,650 & 0,560 & 2,70 & 1,145 & 0,826 & 0,936 \\
\hline $\begin{array}{l}\text { Dijete može oboljeti od zarazne bolesti iako } \\
\text { je cijepljeno protiv nje. }\end{array}$ & 0,602 & & 3,50 & 0,959 & 0,553 & 0,944 \\
\hline $\begin{array}{l}\text { Cjepiva više uzrokuju bolesti nego što ih } \\
\text { sprječavaju. }\end{array}$ & 0,420 & 0,748 & 2,24 & 0,965 & 0,778 & 0,938 \\
\hline $\begin{array}{l}\text { Cjepiva se ne bi trebala davati djeci mlađoj } \\
\text { od jedne godine. }\end{array}$ & 0,565 & 0,500 & 2,54 & 1,118 & 0,709 & 0,940 \\
\hline $\begin{array}{l}\text { Stvaranje prirodnog imuniteta sigurnije je } \\
\text { od cijepljenja. }\end{array}$ & 0,626 & 0,540 & 2,91 & 1,222 & 0,785 & 0,938 \\
\hline $\begin{array}{c}\text { Cijepljenje je izravno povezano s pojavom } \\
\text { autizma kod djece. }\end{array}$ & 0,414 & 0,664 & 2,49 & 0,999 & 0,710 & 0,940 \\
\hline Objašnjeno varijance & 60,81 & 8,19 & & & & \\
\hline
\end{tabular}

KMO 0,928; Bartlettov test $p<0,000$; Ukupno objašnjeno varijance 69,00 \%; Cronbachov alfa 0,944

stima i doveli sumnje u cjepiva kao sigurne metode" (f-test $=5,700$ ). Ako je razlika manja, to je manja disperzija u odgovorima kod ovih skupina.

Druga provedena analiza ANOVA (tablica 5) pokazuje da kod svih tvrdnji postoji značajna statistička razlika u danim odgovorima ispitanika gdje su ispitanici grupirani prema njihovim tvrdnjama povezanima s afirmacijskim pitanjima o cijepljenju. Može se vidjeti da 19 ispitanika ima negativan stav prema cijepljenju djece, 60 ispitanika ima neutralan stav, a 38 ispitanika ima pozitivan stav prema cijepljenju djece. Najviše razlike kod ove druge analize bilo je kod tvrdnje „Više nije potrebno cijepiti djecu jer su te bolesti danas rijetke" (f-test $=44,284$ ), dok je najmanje razlike bilo kod tvrdnje "Dijete može oboljeti od zarazne bolesti iako je cijepljeno protiv nje" (f-test $=15,884)$. 


\section{Tablica 4. Analiza varijance za afirmacijske tvrdnje povezane s cijepljenjem}

\begin{tabular}{|c|c|c|c|c|c|}
\hline \multirow{2}{*}{ Tvrdnja } & \multicolumn{2}{|c|}{ ANOVA } & \multicolumn{3}{|c|}{ PROSJEK } \\
\hline & f-test & Značajnost & $1(62)$ & $2(36)$ & $3(19)$ \\
\hline Cijepljenje djece 100 \% je sigurno. & 16,561 & 0,000 & 3,73 & 3,14 & 2,16 \\
\hline Cijepljenje je sigurno za djecu. & 19,533 & 0,000 & 3,79 & 3,39 & 2,21 \\
\hline Cijepljenje je više korisno nego štetno. & 54,489 & 0,000 & 4,29 & 3,83 & 2,37 \\
\hline Cijepljenje će pomoći da dijete bude zdravo. & 66,471 & 0,000 & 4,24 & 3,44 & 2,00 \\
\hline Potrebno je cijepiti djecu po propisanom programu. & 46,310 & 0,000 & 4,32 & 3,83 & 2,47 \\
\hline Potrebno je cijepiti djecu protiv sezonskih gripa. & 7,005 & 0,001 & 2,97 & 2,67 & 2,00 \\
\hline $\begin{array}{c}\text { Važno je cijepiti stanovništvo kako bi se izbjegla pojava novih } \\
\text { epidemija. }\end{array}$ & 32,146 & 0,000 & 4,24 & 3,50 & 2,21 \\
\hline $\begin{array}{c}\text { Obrazovanje roditelja o cijepljenju važan je način povezivanja } \\
\text { pokrivenosti cijepljenja stanovništva. }\end{array}$ & 27,054 & 0,000 & 4,34 & 3,86 & 2,68 \\
\hline $\begin{array}{l}\text { Rizik od nuspojava cijepljenja prihvatljiv je ako je većina stanovništva } \\
\text { zaštićena od zaraznih bolesti. }\end{array}$ & 28,159 & 0,000 & 3,94 & 3,17 & 2,16 \\
\hline $\begin{array}{l}\text { Liječnik ima važnu ulogu u obrazovanju roditelja o važnosti } \\
\text { cijepljenja u djetinjstvu. }\end{array}$ & 14,098 & 0,000 & 4,40 & 4,11 & 3,42 \\
\hline Davanje više doza istog cjepiva važno je za imunitet djece. & 11,117 & 0,000 & 3,00 & 2,67 & 1,89 \\
\hline $\begin{array}{l}\text { Davanje više cjepiva odjednom nema negativnih utjecaja na imunitet } \\
\text { djece. }\end{array}$ & 9,458 & 0,000 & 2,82 & 2,56 & 1,84 \\
\hline $\begin{array}{l}\text { Mediji su cijepljenje djece povezali s kroničnim bolestima i doveli } \\
\text { sumnje u cjepiva kao sigurne metode. }\end{array}$ & 5,700 & 0,004 & 3,90 & 3,67 & 3,11 \\
\hline
\end{tabular}

\section{Tablica 5. Analiza varijance za negacijske tvrdnje povezane s cijepljenjem}

\begin{tabular}{|c|c|c|c|c|c|}
\hline \multirow{2}{*}{ Tvrdnja } & \multicolumn{2}{|c|}{ ANOVA } & \multicolumn{3}{|c|}{ PROSJEK } \\
\hline & f-test & Značajnost & $1(19)$ & $2(60)$ & $3(38)$ \\
\hline $\begin{array}{l}\text { Farmaceutske kuće propagiraju cijepljenje radi profita iako su cjepiva } \\
\text { štetna. }\end{array}$ & 20,411 & 0,000 & 4,00 & 2,77 & 2,47 \\
\hline Cjepiva sadrže tvari koje su štetne za zdravlje djece. & 25,819 & 0,000 & 3,95 & 2,68 & 2,34 \\
\hline Više nije potrebno cijepiti djecu jer su te bolesti danas rijetke. & 44,284 & 0,000 & 3,37 & 1,98 & 1,66 \\
\hline $\begin{array}{l}\text { Neke su zarazne bolesti nestale zbog bolje higijene pa se djeca ne } \\
\text { moraju cijepiti protiv njih. }\end{array}$ & 30,945 & 0,000 & 3,58 & 2,15 & 1,82 \\
\hline $\begin{array}{l}\text { Bespotrebno je cijepiti djecu protiv zaraznih bolesti koje više ne } \\
\text { postoje. }\end{array}$ & 32,996 & 0,000 & 3,74 & 2,20 & 1,84 \\
\hline Država nema pravo nametati obvezno cijepljenje djece. & 22,492 & 0,000 & 4,21 & 2,87 & 2,21 \\
\hline Roditelji bi trebali donositi odluku o cijepljenju djece. & 20,158 & 0,000 & 4,42 & 3,23 & 2,47 \\
\hline Nema dovoljno dokaza da cijepljenje sprječava zarazne bolesti. & 40,881 & 0,000 & 4,11 & 2,70 & 1,95 \\
\hline Dijete može oboljeti od zarazne bolesti iako je cijepljeno protiv nje. & 15,884 & 0,000 & 4,37 & 3,43 & 3,05 \\
\hline Cjepiva više uzrokuju bolesti nego što ih sprječavaju. & 33,660 & 0,000 & 3,42 & 2,20 & 1,66 \\
\hline Cjepiva se ne bi trebala davati djeci mlađoj od jedne godine. & 26,571 & 0,000 & 3,79 & 2,55 & 1,89 \\
\hline Stvaranje prirodnog imuniteta sigurnije je od cijepljenja. & 27,482 & 0,000 & 4,32 & 2,80 & 2,29 \\
\hline Cijepljenje je izravno povezano s pojavom autizma kod djece. & 19,731 & 0,000 & 3,42 & 2,55 & 1,89 \\
\hline
\end{tabular}




\section{Rasprava}

Istraživanje za potrebe ovoga rada provedeno je na teritoriju Brčko distrikta BiH. Ispitani su stavovi građana prema cijepljenju djece. Pri tome je primijenjen mrežni anketni upitnik. Rezultati koje je dalo ovo istraživanje pokazuju da građani Brčko distrikta BiH imaju stalno mišljenje prema cijepljenju djece bez obzira na to kako su pitanja formulirana. Kod ovoga istraživanja u drugom dijelu anketnog upitnika bilo je 13 afirmacijskih pitanja te 13 negacijskih pitanja povezanih s cijepljenjem djece. Ispitano je imaju li građani koji imaju pozitive stavove u odnosu na negacijske tvrdnje negativne stavove u odnosu na afirmacijske tvrdnje povezane s cijepljenjem djece i obratno. Analiza varijance pokazala je da kod svih tvrdnji postoji značajna statistička razlika u odgovorima ovih skupina, čime se pokazalo da građani Brčko distrikta BiH imaju stalan stav prema cijepljenju i ne mijenjaju ga.

Ono što se može vidjeti iz dobivenih odgovora kod afirmacijskih pitanje jest to da građani nisu baš $100 \%$ sigurni u cijepljenje (prosjek $=3,29$ ), što znači da imaju neutralan i blago pozitivan stav prema sigurnosti cijepljenja, a to je pogotovo prisutno kada je riječ o cijepljenju djece protiv sezonskih gripa ( rosjek $=2,72$ ). Ono što je uočljivo jest to da građani nemaju pozitivan stav prema ponovnom cijepljenju (prosjek $=2,72 ; 2,58$ ). Građani su sljedećega stava: dovoljno je dijete jednom cijepiti protiv određene zaraze, jer koja je šansa da će dijete koje prvi put nije steklo imunitet prema toj zarazi steći imunitet drugi ili treći put pri istom cijepljenju. Ispitanici su stava da su liječnici ti koji najviše mogu utjecati na stav građana prema cijepljenju djece te je potrebno obrazovati roditelje da bi stekli stav prema cijepljenju, što potvrđuje rezultate dobivene u studiji koju su proveli Burghouts i sur., ${ }^{14}$ a također su potvrđeni rezultati dobiveni i u studiji koju su proveli Cvjetković i sur. da liječnici igraju ključnu ulogu u cijepljenju djece, ${ }^{25}$ dok Pelčić ističe da je veoma važna komunikacija liječnika s roditeljima. ${ }^{4}$

Ono što je specifično kod negacijskih pitanja jest to da se ispitanici ne slažu da djecu ne treba cijepiti protiv rijetkih bolesti (prosjek $=2,11$ ), a to potvrđuje disperzija u njihovim odgovorima koja je mala $(S D=0,896)$, što je u protivnosti s rezultatima koji su dobiveni u studiji koju su proveli autori Herzog i sur. ${ }^{33}$ Također, ispitanici se ne slažu s ostalim tvrdnjama o povezanosti higijene i zara- znih bolesti te cijepljenju protiv bolesti koje su danas iskorijene. Ono što je indikativno jest to da se ispitanici ne slažu s tvrdnjom da cijepljenje uzrokuje više bolesti nego što ih sprječava (prosjek $=2,24$ ). Međutim, slažu se da, iako je dijete cijepljeno protiv zaraznih bolesti, svejedno može oboljeti od njih (prosjek $=3,50$ ).

Rezultati ovoga istraživanja pokazali su da ispitanici podržavaju cijepljenje djece, ali nisu sigurni u cijepljenje, što pokazuje da postoji više ispitanika koji imaju negativan stav prema negacijskim tvrdnjama u odnosu na pozitivan stav prema afirmacijskim tvrdnjama. Ispitanici su neutralniji prema afirmacijskim stavovima o cijepljenju djece, ali su osim toga više za cijepljenje nego što nisu jer je samo 19 ispitanika imalo većinu negativnih stavova prema cijepljenju. Potrebno je roditelje i druge interesne skupine informirati o važnosti cijepljenja djece i o tome koje su prednosti cijepljenja, jer su rezultati pokazali da su ispitanici pomalo nesigurni kada je riječ o učincima cjepiva u smislu da ne pružaju 100-postotnu zaštitu od bolesti te da je bespotrebno ponovno i ponovno djecu cijepiti istim cjepivom.

Provedeno istraživanje dalo je nove informacije o stavovima stanovništva prema cijepljenju djece, kao i polazne osnove za daljnje istraživanje stavova stanovništva kako u Brčko distriktu BiH tako i u ostatku BiH, što je znanstveni doprinos ovoga rada. Također, dobiveni rezultati mogu poslužiti za izgradnju strategija za poboljšanje stavova prema cijepljenju djece koje bi trebalo provesti javno zdravstvo.

\section{Zaključak}

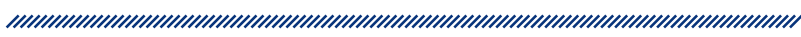

Istraživanje koje je provedeno na području Brčko distrikta $\mathrm{BiH}$ u pogledu stavova prema cijepljenju djece potvrdilo je da su stavovi građana stalni i nepromjenjivi, što su dokazali rezultati analize varijance, čime je prihvaćena hipoteza istraživanja. Također, rezultati su pokazali da je potrebno bolje upoznati stanovništvo $s$ cijepljenjem da bi se podignula svijest stanovništva o cijepljenju.

Nedostatak ovoga istraživanja jest to što nije kreirano više skupina kako bi se usporedili njihovi rezultati, primjerice da su obuhvaćeni i stavovi roditelja koji dovode djecu na cijepljenje i da se vide razlikuju li se njihovi sta- 
vovi u odnosu na stavove građana. Također, trebalo bi usporediti ove rezultate is eventualnim rezultatima koji bi bili dobiveni od onih koji svoju djecu ne dovode na cijepljenje. Na taj bi se način sagledalo zbog čega roditelji dovode djecu na cijepljenje, a zbog čega ne dovode, u cilju kasnijeg djelovanja na stavove stanovništva prema cijepljenju djece. Sve bi se ovo trebalo primijeniti u budućim istraživanjima kako bi se dobio bolji uvid u problematiku cijepljenja. Međutim, za provedbu detaljnijih istraživanja potrebna je potpora javnog zdravstva.

Također, nedostatak je ovoga istraživanja i mali broj ispitanika, ali i bez obzira na to ovo istraživanje daje dobre polazne osnove za ispitivanje stavova prema cijepljenju djece. U buduća istraživanja trebalo bi uključiti više ispitanika $i$ ispitati rezultate u odnosu na neke karakteristike ispitanika kao što su spol, primanja i sl., kako bi se dobili potpuniji rezultati o stavovima stanovništva prema cijepljenju djece.

\section{Referencije}

4. Salmon DA, Teret SP, Maclntyre CR, Salisbury D, Burgess MA., Halsey, NA Compulsory vaccination and conscientious or philosophical exemptions: past, present, and future. Lancet. 2006; 367: 436-442.

5. Čivljak R. Zdravstveni radnici i cijepljenje protiv influence. Medicus, 2011; 20(1): 115-122.

6. Farren E, McEwen M. The basics of pediatric immunizations. Newborn and Infant Nursing Reviews. 2004; 4: 5-14.

7. Pelčić G. Cijepljenje i komunikacija. Medicina fluminensis, 2016; 52(4): 477-485.

8. Greenwood B. The contribution of vaccination to global health: past, present and future. Philosophical Transactions of the Royal Society of London. Series B, Biological Sciences, 2014; 369(1645): 20130433.

9. Dube E, Gagnon D, MacDonald NE. Strategies intended to address vaccine hesitancy: Review of published reviews. Vaccine, 2015; 33(34): 4191-4203.

10. Dube E, Bettinger JA, Halperin B, Bradet R, Lavoie F, Sauvageau C, Gilca V, Boulianne N. Determinants of parents' decision to vaccinate their children against rotavirus: results of a longitudinal study. Health Education Research. 2012; 27(6): 1069-1080.

11. Dahlström LA, Tran TN, Lundholm C, Young C, Sundström K, Sparén P. Attitudes to HPV vaccination among parents of children aged 12-15 years - A population-based survey in Sweden. International Journal of Cancer. 2010; 126(2): 500-507.
12. Ciolli A. Mandatory School Vaccinations: The Role of Tort Law. Yale Journal of Biology and Medicine. 2008; 81(3): 129-137.

13. Habek D, Mušlek A-M. Cijepljenje protiv velikih boginja u Županiji belovarsko-križevačkoj od 1887. do 1907. godine - povijesni osvrt. Infektološki glasnik, 2013; 33(4): 187-190.

14. Kaić B, Gjenero-Margan I, Brzović M, Lakošeljac D, Aleraj $B$, Nemeth-Blažić T, Kolarić B, Macolić-Šarinić V, Šimunović A, Pavlić J. Vaccine Regulations in Croatia. Collegium Antropologicum, 2007; 31,Suppl.2(2): 117-120.

15. Olpinski M. Anti-Vaccination Movement and Parental Refusals of Immunization of Children in USA. Pediatria Polska, 2012; 87(4):381-385.

16. Dube E, Vivion M, MacDonald NE. Vaccine hesitancy, vaccine refusal and the anti-vaccine movement: influence, impact and implications. Expert Rev Vaccines. 2015; 14(1): 99-117.

17. Burghouts J, Del Nogal B, Uriepero A, Hermans PWM, de Waard JH, Verhagen LM. Childhood Vaccine Acceptance and Refusal among Warao Amerindian Caregivers in Venezuela; A Qualitative Approach. PLoS ONE. 2017; 12(1): e0170227.

18. Ruijs WL, Hautvast JL, van ljzendoorn G, van Ansem WJ, van der Velden K, Hulscher ME. How orthodox protestant parents decide on the vaccination of their children: a qualitative study. BMC Public Health, 2012; 12(408): 2-11.

19. Andreykanich S, Rode M, Oroši D, Škrabić I, Vukelić D. Prednosti i nedostaci cijepljenja protiv vodenih kozica i herpes-zostera. Infektološki glasnik, 2016; 36(2): 61-68.

20. Rodin U. Evaluacija akcijskog plana za Rome za područje zdravstva. Acta medica Croatica, 2010; 64(5): 327-333.

21. McKee C, Bohannon K. Exploring the Reasons Behind Parental Refusal of Vaccines. The Journal of Pediatric Pharmacology and Therapeutics, 2016; 21(2): 104-109.

22. Turkalj M, Erceg D. Alergijske reakcije na cjepiva. Liječnički vjesnik, 2012; 134(5-6): 173-177.

23. Yaqub O, Castle-Clarke S, Sevdalis N, Chataway J. Attitudes to vaccination: A critical review, Social Science \& Medicine, 2014; 112: 1-11.

24. Gagro A. Vaccinating an Immunocompromised Child. Periodicum biologorum, 2012; 114(2):167-174,

25. Streefland P, Chowdhury AMR., Ramos-Jimenez P. Patterns of vaccination acceptance. Social Science \& Medicine, 1999; 49(12): 1705-1716.

26. Hobson-West P. Understanding vaccination resistance: moving beyond risk. Health, Risk \& Society. 2003; 5(3): 273-283.

27. Favin M, Steinglass R, Fields R, Banerjee K, Sawhney M. Why children are not vaccinated: a review of the grey literature. International Health, 2012; 4(4): 229-238.

28. Cvjetkovic SJ, Jeremic VL, Tiosavljevic DV. Knowledge and attitudes toward vaccination: A survey of Serbian students. Journal of Infection and Public Health. 2017; 10(5): 649-656.

29. Puntarić D, Stašević I, Ropac D, Poljičanin T, Mayer D. Neki pokazatelji zdravstvenog stanja stanovništva Republike Hrvatske. Acta medica Croatica, 2015; 69(1): 3-14. 
30. Pelly LP, Pierrynowski Macdougall DM, Halperin BA, Strang RA, Bowles SK, Baxendale DM, McNeil SA. The Vaxed Project: An Assessment of Immunization Education in Canadian Health Professional Programs. BMC Medical Education, 2010; 10: 86.

31. Mollema L, Staal JM, van Steenbergen JE, Paulussen TG, de Melker HE. An exploratory qualitative assessment of factors influencing childhood vaccine providers' intention to recommend immunization in the Netherlands. BMC Public Health, 2012; 12: 128.

32. Lameris M, Schmidt C, Gleberzon B, Ogrady J. Attitudes toward vaccination: A cross-sectional survey of students at the Canadian Memorial Chiropractic College. The Journal of the Canadian Chiropractic Association, 2013; 57(3): 214-220.

33. Yousif MA, Albarraq AA, Abdallah MAA, Elbur Al. Parents' Knowledge and Attitudes on Childhood Immunization, Taif, Saudi Arabia. Journal of Vaccines \& Vaccination, 2013; 5(1): 1000215.
34. Elbur Al, Yousif MA, Albarraq AA, Abdallah MA. Knowledge and Attitudes on Childhood Vaccination a Survey Among Saudi Parents in Taif Region, Saudi Arabia. International Journal of Pharmacy Practice \& Drug Research. 2014; 4(2): 92-97.

35. Puška A, Maksimović A, Fazlić S. Utjecaj kvalitete na zadovoljstvo i lojalnost studenata. Poslovna izvrsnost. 2015; 9(2): 101-119.

36. Herzog R, Álvarez-Pasquin MJ, Díaz C, Del Barrio JL, Estrada JM, Gil Á. Are healthcare workers' intentions to vaccinate related to their knowledge, beliefs and attitudes? A systematic review. BMC Public Health. 2013; 13: 154. 


\section{POPULATION ATTITUDES ON CHILDHOOD VACCINATION IN BRCKO DISTRICT OF BEH}

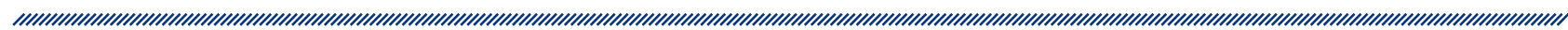

\begin{abstract}

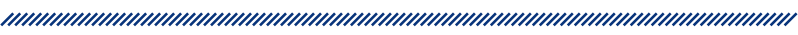

Vaccination represents the greatest achievement in medicine for the treatment of infectious diseases. Thanks to the vaccinating, some infectious diseases are eradicated, while others are almost eradicated. However, even with all these facts, some parents do not vaccinate their children. This is due to their views with regard to the vaccination. This paper explored population views with regard to the vaccination. The survey was conducted on the territory of the Brcko District of $\mathrm{B} \& \mathrm{H}$, via an online questionnaire. Firstly, the results of the conducted survey were obtained, and secondly, the results of the claims in regard with the vaccination were examined. Exploratory factor analysis (EFA) grouped both groups of claims into two factors.

Investigating population attitudes towards vaccination has been conducted with two groups of questions; i.e. 13 affirmative and negative questions about vaccination. Based on the responses received, grouping of respondents according to their attitudes was the following: in case where the most respondents were positive, they were grouped in a group of respondents who had a positive attitude and vice versa. It was also noted if respondents who had a negative attitude towards negative issues had a positive attitude towards affirmative questions and vice versa. The variant analysis has shown that attitudes of respondents are unchanged and constant. This research has provided good grounds for understanding the attitudes of the population towards the vaccination of children, which would be further deepened in future research and would serve to develop strategies for the vaccination of children in public health.
Keywords: childhood vaccination, population attitudes, vaccination, factor analysis, variant analysis. 